\title{
PSYCHIATRY ASPECTS OF CONSPIRATION THEORY IN COMMUNITY DUE TO COVID-19
}

\author{
Ismail Afandi Kalam ${ }^{1}$, Zuhrotun Ulya ${ }^{2}$ \\ Correspondence: afandi04.ak@gmail.com \\ ${ }^{1}$ Alumni FK Universitas Brawijaya (dokter internship), ${ }^{2}$ Psychiatry Department Rumah Sakit Universitas Brawijaya
}

Article History:

Received: May 19, 2020

Accepted: June 28, 2020

Published: September 28, 2020
Cite this as: Kalam, I.A \& Ulya, Z. Psychiatry aspects of conspiration theory in community due to covid-19..

Journal of Psychiatry Psychology and Behavioral Research; 2020. 2: 5-4.

\section{INTRODUCTION}

Coronavirus disease (COVID-19) cases spread throughout the world and was declared as pandemic on March $2020 .{ }^{1}$ The accelerated increase in cases and mortality rates accompanied by lack of information or knowledge induce anxiety and fear in community. ${ }^{2}$ Perceived anxiety, fear and uncertainty encourage people to seek explanations to reduce their anxiety, try to regain control over the situation which becomes conspiracy theory. ${ }^{3}$ Conspiracy theory become an unsubstantiated belief that there is a role for huge and evil forces planning for hidden purposes. ${ }^{2}$ For nowadays, this is not only become as new phenomenon but also existed for real in society especially in some social crises.

\section{METHOD}

This article will discuss about some issues of psychiatric aspects of conspiration theory based on literature review.

\section{DISCUSSION}

Coronavirus as pandemic in the world

COVID-19 characterized by the presence of fever accompanied by respiratory symptoms, such as cough and shortness of breath which vary from mild to severe. Clinicians found other symptoms which involve another part of body.
Severe cases of COVID-19 can lead to acute respiratory syndrome, kidney failure and death. ${ }^{4}$ In Indonesia on early September 2020 was found 4000 new cases a day, more than 9.000 patient death due to COVID-19. ${ }^{5}$ This pandemic still go on over the world, there were more than 2 million cases. ${ }^{6}$ Some unknown aspects of the disease, such as viral, comorbidity, definitive antiviral therapy, effectiveness of vaccination's raise global concerns about this pandemic. ${ }^{3}$ Prevention aspects was the main approach to inhibit the spread of virus. Physical distancing and quarantine strictly enforced in the world. How to keep avoid in crowded places, keep their distance, avoid physical contact, ethics of cough and sneezing, until improvement of personal hygiene such as washing hands, disinfecting object, using masks and gloves educate in community. Several countries have carried out regional quarantine and closed the entry and exit routes. ${ }^{2}$

\section{Coronavirus and Community Mental Health}

Coronavirus give another impact on community mental health. Lack of knowledge, spread of hoax information, amount of excessive coverage in social media and overvalued of explanations symptoms increases people's anxiety and fear. This is called infodemic, which is a condition when there is too much information obtained then makes it difficult for someone to determine which one is reliable sources of information. ${ }^{7}$ These condition cause someone or community become anxious 
and lose their control of what they are facing. ${ }^{3}$ When the environment changes, people will become insecure, uncomfortable and anxious due to their adjustments. This condition lead to loneliness, denial, anxiety, depression, insomnia and feelings of hopelessness, which can decrease on adherence to medication. ${ }^{7}$ Fear and anxiety caused by the COVID-19 pandemic can have harmful effects on mental health, causing negative psychological and social impacts on society. ${ }^{2}$

\section{Development of conspiracy theories in crisis conditions}

Perceived anxiety, fear and uncertainty encourage people to seek more reassurance and explanations to reduce their anxiety and try to regain control over the situation. Crisis conditions and tense events, such as those currently occurring, have increased public confidence in conspiracy theories. Conspiracy theories are unsubstantiated beliefs that there is a role for large hidden agenda or purposes, this will induce a mechanism of rationalization of conditions that aims to provide a sense of security and give meaning to an event. ${ }^{3}$

Previous research has revealed that increasing belief in conspiracy theories during times of pandemics is not a new phenomenon. Especially during times of crisis, the belief in conspiracy theories has increased significantly. ${ }^{4}$ The same thing happened during the pandemic or previous outbreak, for example during the HIV and Zika outbreaks, conspiracy theories spread over the world that the virus was deliberately created by the state to destroy certain groups for certain purposes. ${ }^{4}$ Another conspiracy theories arises under certain conditions, such as issues of global warming, NASA, the deaths of Princess Diana and John F. Kennedy, 9/11 terrorist attacks and so on. ${ }^{8}$ Conspiracy theories will preferred in confusing and difficult situations because they provide a simpler explanations of what happened so that an even fells "plausible". 9 Meanwhile, it will became a scapegoat to blame for the situations. During the COVID-19 pandemic, various conspiracy theories have also developed in society. A survey conducted in the US in March showed that $49 \%$ believed that pandemic was a man-made epidemic, $44 \%$ said it exaggerated by political purposes, and $13 \%$ believed that is just a hoax. ${ }^{4}$

\section{Factors influencing the formation of Conspiracy Theories in Society}

Uncertainty and a feeling of losing control became the main factors that arises of conspiracy theories which provide causal explanations for social events that cause anxiety. This is a process to make sense of things, by seeing the world as an orderly, easy to understand, and predictable system, this understood well because human still need to be safe, comfort in their environment and to how to control theirs as individuals who autonomous, free and as part of society. This rationalization is unfounded, sometimes associated with low levels of analytical thinking. ${ }^{10,11}$ Research by Sallam revealed that low levels of knowledge and high level of anxiety are linked to the belief that the disease COVID-19 is part of global conspiracy. $^{2}$

This thought process itself is a major part of "social paranoid cognition", a state of mind that contains suspicion, characterized by high alertness to the possibility of other people's bad intentions. ${ }^{10}$ This is related with paranoid idea, namely the belief in an external agent who has bad intentions towards him. ${ }^{8}$ Conspiracy thinking is similar with paranoia, where in a state of suspicions, the individual is constantly afraid of the dangers caused by external factors. ${ }^{8}$
Belief in conspiracy theories becomes stronger when the motivation to find patterns in the environment increases, as well as in people who frequently look for meaning and patterns in events. This trait is often seen in people who believe in paranormal phenomen. ${ }^{10}$ Research reveal there are positive associations between conspiracy theories and paranoid, paranoid ideas and paranormal beliefs. ${ }^{8}$ Paranoid ideas and paranoid phenomenon are associated with schizotypal personality characteristics. Schizotypal is a prodromal phase of schizophrenia characterized by cognitive, perceptual and affective symptoms. Characteristics of schizotypal include suspicions, magical thinking, social anxiety, paranoid, with schizotypal individuals generally having strange and extraordinary beliefs. ${ }^{8}$ Distrust nature seen in individuals with schizotypal causes individuals tend to distrust the main sources of information. The characteristics associated with paranoid ideas lead to distorted perceptions and mistaken inventions that lead to conspiracy ideas. This is evidenced by the existence of research that shows a significant and positive relationship between conspiracy theory beliefs and schizotypal. ${ }^{9}$

In addition, conspiracy theories are thought to be linked to narcissism, which related with needed of external validation and paranoid ideas. Conspiracy theories can be used to fulfill the need to maintain self and group images. Conspiracy theories can validate self-image and group by blaming others for negative consequences. Therefore, conspiracy theories are favored by individuals and groups who are in a position to be threatened to reduce or neutralize their experience. Research shows that conspiracy theories are strongly associated with a lack of socio-political control or a lack of psychological empowerment. ${ }^{11}$

\section{Conspiracy theories effects on people's behavior in facing pandemics}

Conspiracy theories suppress individual autonomy and control of situations. This occurs because conspiracy theories tend to lead to disobedience to norms and rules, which in turn can prevent individuals from gaining autonomy and control rights. In addition, since conspiracy theories state that the events that occur are controlled by an evil force that has power beyond legitimate limits, this creates a feeling of helplessness, which in turn can increase anxiety. ${ }^{11}$

Conspiracy theories generally involve governments or stakeholders. In uncertainty conditions, people generally pay more attention to morality and government policies or stakeholders because society only depend on those. If societies think that the government not doing enough to cope the situations, this can increase the feelings of helplessness in community. ${ }^{3}$ Increased belief in conspiracy theories related with decrease of trust level in government accompanied by a decrease in behavior in accordance with social norms and acceptance of science. ${ }^{9}$ In addition, belief in conspiracy theories makes adherents tend to engage in illegal and nonnormative actions to achieve certain goals, because people who believe in conspiracy theories see their actions was part of defensive reaction. ${ }^{4}$

Society's behavior in COVID-19 pandemics depends on what they believed. People who believe that a pandemic is a hoax tend to disobey recommended preventive measures, while people who believe that COVID-19 is a human-made epidemic tend to take excessive preventive action, which is usually focused on oneself. A study conducted by Imhoff revealed that believing COVID-19 pandemic is a negative predictor of 
preventive actions such as washing hands and doing physical distancing. ${ }^{4}$

\section{CONCLUSION}

Conspiracy theories not a new phenomenon in society, it will increase with social crises, blow up of terrorism issue, disease outbreak and related with anxiety and helplessness even though the condition can explain well with evidence based. Rationalization from this condition made society feel safe, comfort, hold and control their environment well but it also related with paranoid, paranoid ideation, schizotypal personality and belief of magical thinking. Conspiracy theories cannot stop spreading on COVID-19 pandemic and will arising another hoax. Beliefs in conspiracy theories lead to distrust of the government and stakeholders, illegal behavior that is considered defensive, increased feeling of helplessness and anxiety, and excessive behavior related with how to cope this pandemic.

\section{Conflict of interest}

No conflict of interest in this study.

\section{References}

1. Kementerian Kesehatan Republik Indonesia. 2020. Pedoman Pencegahan dan Pengendalian Coronavirus Disease (COVID-19). Direktorat Jenderal Pencegahan dan Pengendalian Penyakit revisi ke-3. Maret, 2020.

2. Sallam, M., et al. Conspiracy beliefs are associated with lower knowledge and higher anxiety levels regarding COVID-19 among students at the University of Jordan. medRxiv.

2020 , https://doi.org/10.1101/2020.04.21.20064147

3. Srol, J., Mikuskova. E.V., Cavojova, V. When We Are Worried, What Are We Thinking? Anxiety, Lack Of Control, And Conspiracy Beliefs Amidst The Covid-19 Pandemic. 2020, Karya tidak dipublikasikan.

4. Imhoff, R., Lamberty, P. A bioweapon or a hoax? The link between distinct conspiracy beliefs about the Coronavirus disease (COVID-19) outbreak and pandemic behavior. 2020.

5. Satgas Tugas Penanganan COVID-19. 2020. Peta Sebaran. Covid19.go.id/peta-sebaran.

6. Alper, S., Bayrak, F., Yilmaz, O. Psychological Correlates of COVID-19 Conspiracy Beliefs and Preventive Measures: Evidence from Turkey. 2020.

7. Ren S.Y., Gao R.D. 2020. Fear can be more harmful than the severe acute respiratory syndrome coronavirus 2 in controlling the corona virus disease 2019 epidemic. World J Clin Cases. 2020, February 26; 8(4): 652-657

8. Darwin, H., Neave, N., Holmes, J. Belief in Conspiracy Theories. The Role of Paranormal Belief, Paranoid Ideation, and Schizotypty. Personality and Individual Differences. 2011, 50(2011): 1289 - 1293

9. Swami, V., Weis, L., Lay, A., Barron, D., Furnham A. Associations between Belief in Conspiracy Theories and the Maladaptive Personality Traits of the Personality Inventory for DSM-5. Psychiatry Research. 2015, doi: http://dx.doi.org/10.1016/j.psychres.2015.12.027

10. Van Prooijen, J.W., Jostmann, N.B. Belief in Conspiracy Theories: The Influence of Uncertainty and Perceived Morality. Eur. J. Soc. Psychol. 2012, 43, 109-115 (2013) 